\title{
THE IDEAL TABLE GRAPES FOR THE SPANISH MARKET ${ }^{1}$
}

\author{
CESAR ROSSO PIVA ${ }^{2}$, JOSÉ LUIS LOPEZ GARCIA ${ }^{3}$, WYN MORGAN ${ }^{4}$
}

\begin{abstract}
This paper seeks to explore a survey of consumers in Spain. The survey explores the attributes of quality that consumers are seeking and promotion of grapes via "quality" marks, which are indicators of possible ways to increase demand. The reason consumers are switching to other foods, such as dairy based snacks, is that grapes are not easy to eat, can be unreliable in terms of their quality attributes, and their price more variable. Consumers are also generally unaware of the marks quality currently used.
\end{abstract}

Index Terms: Table grapes, consumer survey, consumers' preferences, quality attributes.

\section{A UVA DE MESA IDEAL PARA O MERCADO ESPANHOL}

RESUMO - Este trabalho busca explorar o mercado da uva de mesa na Espanha, do ponto de vista do consumidor. O estudo explora os atributos de qualidade que os consumidores estão buscando e a promoção da uva de mesa via marcas de "qualidade" com a possibilidade de incremento de demanda. A importância deste estudo reside na mudança que vem ocorrendo no hábito de consumo de alimentos, onde as frutas e verduras em geral, e a uva de mesa em particular têm perdido espaço para produtos prontos para o consumo, como os derivados lácteos , doces e sobremesas. Em contraste, a uva de mesa não se apresenta pronta para o consumo, possui qualidade de fruta e preços mais variáveis, e o conceito de marca comercial encontra-se ainda pouco estabelecido, ao contrário dos produtos industrializados.

Palavras-chave: uva de mesa, estudo do consumidor, preferências dos consumidores, atributos de qualidade.

\section{INTRODUCTION}

The consumption of table grapes in Spain has declined over the last twenty years (Piva, 2001) with potentially significant impacts on Spanish producers. Consequently, producers of "traditional" products, such as grapes, need to ensure that they can adapt to the changing nature of consumption in the market and be aware of the expectations consumers have of such products. In 2004, when this article was already written, a Spanish national association for table grapes was created in Murcia (Spain) by producers and researchers.

Studies of grape characteristics and their relationship with consumer preferences are relatively scarce. Various papers have examined the maturation process of the grape (for example, Nedelchev \& Kondarev (1934), Amerine \& Thoukis (1958), and others). However, these papers have focussed on the biological aspects that influence the maturing process, rather than the characteristics that the consumer desires in grapes.

Work in the more consumer-oriented field is varied. Domingo \& Herrera (1970) examined the Argentinean market and showed that consumers' tastes varied with maturity and the degree of sugar and acidity in the grapes. Alavoine (1992) showed that the quality of taste of new varieties was important. Cliff et al (1996) showed the results of evaluating twelve different types of table grape through eleven visual and ten flavour and texture attributes, along with their relation with visual and taste preferences. The outcomes of these tests were used to help the naming of new varieties of grapes to maximise the impact on consumers.

Leong et al (1996), studied socio-economic characteristics and the consumer's perceptions of the varieties moscatel (muscadine) and Thompson Seedless in the US. Their results suggest that two key variables that encouraged consumption were, taste and price.

In considering the issue of what attributes consumers want from grapes, this paper will examine the market from the consumer side and, unlike Poole (2000), it will not try to suggest strategies for producers to follow to improve their market position. In considering the grape individually, it is possible that consumers do not feel that the quality of the product is high enough or that the attributes of them are attractive enough to entice consumption. The survey undertaken here is an attempt to elicit data on such views.

\section{MATERIALS AND METHODS}

\section{Design and Application of the Sample Questionnaire}

Madrid represents the Spanish consumer behaviour because is the geographical centre and capital of Spain and, historically Madrid has drawn its population from the surrounding regions and thus the Madrid market acts as a good indicator of consumption patterns in the wider Spanish market (MAPA, 2000).

The survey was carried out on a district by district basis and of the 21 districts that comprise the sample frame, 16 were eligible to be used in the survey as the rest lay outside the area of study (Piva, 2001). The main criterion for the choice of districts was the representative population of each one of them. The 16 districts comprise $88.1 \%$ of the total population of the Madrid area.

The questionnaires were completed using street-based personal interviews with consumers between November 1999 and the middle of January 2000. The questionnaire comprised 25 questions relating to attributes and quality, relevant personal data (e.g. sex, age, level of education and income) and to consumer knowledge of seedless and branded grapes. The intention of the latter questions was to explore ways forward for producers - would new varieties (such as seedless ones) be more attractive or would increased advertising and branding create a "better" image for Spanish grapes and induce greater consumption? The questions included open, closed and semi-closed forms and the interviews were carried out following the random stratified sample model.

The number of interviews in each district was decided on the basis of proportionality to the number of inhabitants of the district. Once the number of interviews had been decided, a proportion based on the age of its inhabitants, grouped in sections, was decided for each one of the districts. Data from the interviews with consumers was tabulated using Excel 97 for Windows 95 with statistical analyses carried out using SPSS. The data from the 450 valid interviews are presented.

In addition, to corroborate opinions and comments on attributes and likes/dislikes, tasting tests were used after the questionnaires had been completed and where appropriate the results of these have been commented.

\footnotetext{
$\overline{1}$ (Trabalho 021-2005). Recebido: 08-08-2005. Aceito para publicação: 30-05-2006. Extraído da tese de doutorado do primeiro autor, apresentada à Universidad politécnica de Madrid/Espanha.

${ }^{2}$ Eng. Agr., D.Sc. Bal. Gaivotas, Cep. 88955-000, Santa Catarina.- BR. Crpiva@yahoo.com

${ }^{3}$ Eng. Agr., D.Sc. prof. do Dpto de Economia y Ciencias Sociales Agrárias, E.T.S.Ingenieros Agrónomos, Universidad Politécnica de Madrid. Ciudad Universitaria s/n 28040-Madrid/ES. jllopez@eco.etsia.upm.es.

${ }^{4}$ D.Sc. Senior Lecturer. School of Economics, University of Nottingham, Nottingham - UK. NG7 2RD. e-mail: Wyn.Morgan@ nottingham.ac.uk
} 


\section{RESULTS AND DISCUSSIONS}

\section{Consumers' Profile}

About the age, the interviewees sample and the "universe" (Madrid's population), both have similar percentages distribution within the age intervals. So, the sample obtained for this survey it is very representative of the universe (Madrid's population).

Of the 450 interviewees: $52.4 \%$ were women and $47.6 \%$ were men.

These percentages are again very similar to those from the census of the Madrid population.

\section{In terms of education}

- $39 \%$ of the sample had a higher level of education,

- $\quad 33 \%$ had a secondary level of education and,

- $21 \%$ had the basic level of schooling only.

The sample revealed that the most common size of the family nucleus:

- 4 people $(35.8 \%)$

- it was 3.66 the median number of people in a family.

The survey revealed that about level of income:

- $\quad 47 \%$ of the respondents had a lay between 51000 ptas $(\bullet 306,51)^{5}$ and 100000 ptas $(\bullet 601,01)$,

- $\quad$ the median income per capita was 100790 ptas $(\bullet 605,76)$ with the deviation being 62760 ptas $(\bullet 377,19)$.

The household shopping:

- $65 \%$ of cases, the woman of the house (generally the mother) is in charge of it.

- $16 \%$ the responsibility for shopping is shared between two or more people.

- $6 \%$ the father is the third most common response, followed by

- $5 \%$ children.

Consumers' Preferences

Consumption of Fruit including Table Grapes

The quantity of fruit bought weekly

- $\quad 54.2 \%$ stated that was between 4 and $7 \mathrm{kgs}$

- $\quad 23.6 \%$ buying between 1 and $3 \mathrm{kgs}$.

The weekly consumption of fruit per head is $1.67 \mathrm{kgs}$, which corresponds to annual fruit consumption per head in Madrid of approximately $87.2 \mathrm{kgs}$ (Piva, 2001), a figure consistent with national figures (MAPA, 1999b).

A relationship cannot be seen between the frequency of consumption of grapes in season (August to December) and the income per capita of the consumer, his/her social class or his/her level of education.

Where grapes were bought (see Table 1): the majority of respondents $(50.0 \%)$ suggest that they usually buy grapes predominantly from "traditional" shops, which consist of local fruit markets (39.0\%) and corner stores (11\%). The (14.4\%) of grapes are bought in supermarkets and (10.2\%) in hypermarkets. A comparison with MAPA (1999b) data is given in Table 1.

According to Fernandez (2000), $72 \%$ of buyers in fruit and vegetable shops in Madrid are between 45 and 60 years old. From this

TABLE 1 - Place where Grapes and Fruits are Usually Bought

\begin{tabular}{lcc}
\hline Type of Establishment & Survey (\%) & M.A.P.A (\%)* \\
Traditional Shops & 50.0 & 41.8 \\
Supermarkets & 14.4 & 24.5 \\
Hypermarkets & 10.2 & 9.1 \\
Others & 25.4 & 24.6 \\
\hline
\end{tabular}

*Source: Derived from MAPA (1999b) we can deduce that the younger generations prefer to buy in large supermarkets and hypermarkets.

The survey reveals that $72.4 \%$ of the respondents eat fruit every day, although seasonal variations in consumption are apparent. In spring/summer, the most popular fruits were watermelons and melons, followed by peaches and nectarines. Table grapes were the favourite fruit in only $2 \%$ of households. In autumn/winter, preference inclined towards oranges and mandarins followed by apples and bananas. Table grapes appear in fourth place with $11 \%$ of the preferences.

\section{Origin \\ Knowledge of commercial brands and the Denomination of}

Knowledge on the part of the consumer of commercial marks for grapes is practically non-existent. Of the $6 \%$ of interviewees, who claimed some knowledge of the commercial marks, upon naming them always referred to varieties - mainly Moscatel.

Several factors contribute to this. One is the way in which the grapes are presented to the consumer. On the whole, they are sold to the public loose. In the markets, when packed, it generally carries the name of the shop, the distributor or the packer and not the producer. In addition, as consumption is so low, exposure to these marks is not significant or regular and thus reinforcement through repetition does not occur. Moreover, labels on the bunch are sometimes present although not frequently, and when they the labels are only found on grapes from South Africa, Chile and the Vinalopó valley, branded by the "Denominacion de Origen" (DO) "Uva de Mesa Embolsada" del Vinalopó" label. The aim of the DO is to promote grapes from that region and to use the label as a sign of quality. The "embolsada" grape of the Vinalopó valley has been marketed under DO since 1992 and the marketed volume in 1999 under DO was around 16,000 tons, that means $20 \%$ of the total volume of grapes marketed at national level (MAPA, 1999c). The DO has tried to engage in advertising to raise awareness of grapes amongst consumers.

The tasting test evidence of preference between the grape Italia from the Vinalopo valley (DO) and the same variety from Sicily, suggested that the Spanish grape is preferred to the imported one, mainly due to better firmness, lack of pips, juiciness and taste.

\section{Knowledge and opinions about seedless varieties}

Given earlier remarks about the "inconvenience" of fruit including grapes, the survey posed specific questions about seedless grapes, which should be "easier" to consume.

Just only $20 \%$ of respondents had tried seedless grapes, and of these:

- $58 \%$ have a positive opinion about them,

- $16 \%$ that did not like them because of their poor taste

- $\quad 26 \%$ felt there was no difference between seedless and other grapes.

The highest proportion of those who had tried seedless varieties was in the age group 45 and over. However, there was no correlation between age and the opinion expressed.An interesting comparison is between consumer and retailer perceptions of seedless grapes. When the consumer was in a retail shop, the retailer was asked about the seedless grapes too. Retailers, on the whole, have a negative opinion while consumers on the whole are positive. The retailers, expressing what they think are the consumers want, overstate the importance of size and colour and understate the importance of thinness of skin and the lack of seeds. Size and colour are selling stimuli, but a thin skin makes the grape last shorter. Moreover, retailers consider price to be a sign of quality valued by the consumer. These findings mirror those of Lopez \& Briz (1985).

\footnotetext{
5 These days the new currency is the Euro. $1 \bullet=166,386$ ptas.

6 .-"Embolsada", because the grape is wrapped with a paper bag ("bolsa"), to protect it from damages as it grows in the vine.
} 


\section{Quality Attributes}

The characteristics that a quality grape should posses, according to the consumer are given below. To obtain the consumer's view of grape quality, the following question was asked: what characteristics do you think a quality grape should have? It was an open question and without suggestion. The replies had a total of 1118 different key words (sometimes phrases). After grouping them for similarity they were recorded and are shown in Table 2.

- $26.7 \%$ of the total mentioned the word 'sweet' and appeared 298 times.

- $\quad 15.8 \%$ is the attribute 'thin skin' with 177 appearances.

- $10.0 \%$ were aspects relating to seeds (with the answers suggesting consumers want no seeds, few seeds, or small seeds).

- $8.9 \%$ were mentions relating to size, and

- $6.5 \%$ juiciness.

TABLE 2 - Key Quality Characteristics According to Consumers.

\begin{tabular}{lcc}
\hline Characteristics & $\%$ & Cummulative \% \\
Sweet & 26.7 & 26.7 \\
Thin skin & 15.8 & 42.5 \\
Few/no seeds & 10.0 & 52.5 \\
Large size & 8.9 & 61.4 \\
Juice & 6.5 & 68.0 \\
Good taste & 5.1 & 73.1 \\
Colour & 4.4 & 77.5 \\
Good looking & 4.0 & 81.5 \\
Maturity & 3.0 & 84.4 \\
Good conservation & 3.0 & 87.4 \\
Hard & 2.5 & 89.9 \\
Others & 10.1 & 100.0 \\
\hline Total & 100.0 & 100.0 \\
*Source: Derived own survey & &
\end{tabular}

As for colour, most mentions quoted 'good colour' and those that specified wanted golden or yellow.

The phrase 'keep well' appeared as a generic term. Also, words such as clean, not pitted, whole, etc. were grouped together. The table grape can last among one week and 10 days after being harvested. This period is only indicative given that conservation depends on a range of factors such as maturity, care taken during harvest, transport, temperature of warehousing, packaging etc. In perfect conditions, the grape can be kept for up to two or three months according to the variety. As such, consumers clearly want a wellpresented and robust grape, which might be difficult to provide given the perishable and delicate nature of the fruit. Related to seeds, the data obtained from the sensory analyses carried out in the taste tests corroborate that already expressed, specifically that pips are undesirable in grapes. The seedless varieties, Flame and Sugraone, gained average scores significantly superior for 'seed' characteristics compared to varieties that contain seeds. Skin texture, size of grape and the presence of seeds (in quantity or size) are intrinsic characteristics of the variety. However, through modern growing techniques some aspects can be improved. For example, covering the clusters on the vine intensifies the taste, aroma and colour of the grape (Martinez, 1997), or by using hormones one can induce seedlessness or increase the size of the grapes (Pommer et al., 1996).

The presence of green grapes (which are more acidic) in the market place, usually occurs at the beginning of the season, when the prices are more attractive for the producer and the seller. This produces, on the whole, negative effects on consumption, for when the consumer tries green, unripe grapes, he/she will not return to buy more for several days, as he/she is waiting for the grapes to ripen. This can cause a significant decline in consumption over several days, or it can cause outright rejection in the future, as the consumer thinks that the acidity is due to the variety (Domingo \& Herrera, 1970).

As the consumer values taste (sweet and not very acidic), the level of ripeness can determine the success or failure of a new variety as soon as it is introduced into the market. To give an example, the seedless variety Sugraone, produced in Murcia, is well accepted in the English market. It is a grape of seasonal ripeness (July) and although it is slightly green, it is accepted. To introduce this variety in the Spanish market, in these conditions, would appear to guarantee the failure of this variety.

Bruises, decay and over-ripeness are related defects that can arise in the harvesting and pre harvesting processes and also the climate in these periods. In addition, as the grape is basically sold in bulk, principally in traditional shops, the lack of special care and the rough handling of the retailer encourage the appearance of such problems.

\section{CONCLUSIONS}

1) According to the consumers, the attributes for the ideal grape and which define the quality of the grape, are in decreasing order:

- $\quad 26.7 \%$ a good taste/sweetness,

- $15.8 \%$ thin skin,

- $10.0 \%$ the absence of pips,

- $\quad 8.9 \%$ size, and

- $6.5 \%$ keeps well (juiciness).

2) So, the ideal table grapes for the Spanish consumer should be, and in this order: sweet, with thin skin, no seeds, large size, and juicy.

3) The consumer, in general, does not distinguish between varieties of grape.

4) A large number of synonyms are used for one variety and at times, generic names such as white grapes or black grapes are used.

5) They neither know the commercial brands nor the Denomination of Origin 'Vinalopó', which is the only one existing.

6) In addition, the retailer and the consumer disagree upon the value of the attributes of quality of table grapes.

7) The results of the survey suggest that there are many ways forward for producers and retailers of grapes if they are to arrest the decline in consumption of grapes.

8) Clearly, there are improvements to be made in the type and quality of grape supplied, especially with seedless grapes.

9) Greater care in handling and packaging grapes will ensure a longer shelf life and thus increase consumer confidence in the product.

10) However, if improved quality can be developed in line with more targeted advertising campaigns then there might well be positive returns to producers.

\section{REFERENCES}

ALAVOINE, M. F. Etude de la qualité gustative de nouvelles varietes de raisin de table. Revue d'Informations Techniques du CEMAGREF, Paris, n.86, p 1-7, 1992.

AMERINE, M. A.; THOUKIS, G. The glucose-frutose ratio of California grapes. Vitis, Siebeldingen, v.1, p. 224-229, 1958.

CLIFF, M.A., DEVER, M.C.; REYNOLDS, A. G. Descriptive profiling of new and commercial British Columbia table grape cultivars. American Journal of Enology and Viticulture, California, v.47, n.3, p. 301-308. 1996.

DOMINGO R. M.; HERRERA, E. J. Preferencias de los consumidores de uvas de mesa en relación al grado de madurez. IDIA, Argentina, n.275, p. 1-12, 1970.

FERNÁNDEZ RODRIGUEZ, R. Alternativas estratégicas para los mercados minoristas tradicionales: Análisis desde la óptica de la oferta en los mercados de Madrid. Distribución y Consumo, Madrid, n.49, p. 45-65, 2000. 
LEONG, S.; LAMIKANRA, O.; THEODORE, L. Analyzing the socioeconomic characteristics and consumer perceptions of tables grapes: Fly vs Thompson seedless. Proceedings of the Florida State Horticultural Society, Winter Haven, n.109, p. 242-245. 1996.

LÓPEZ GARCIA, J.L.; BRIZ ESCRIBANO, J. El comportamiento del mercado de Madrid de fruta dulce. In: CONGRES INTERNATIONAL DE LA FRUITA DOLÇA, 1., 1985, Lleida. Annals...p. 153-160.

M.A.P.A. La alimentación en España. Madrid: Secretaria General de Agricultura y Alimentación. Madrid: M.A.P.A., 1999b. 485p.

M.A.P.A. Datos de las D.O. y Específicas de productos agroalimentarios. Madrid: Secretaria General de Agricultura y Alimentación- Subdirección General. Denominaciones de Calidad, 1999c. 101p.

M.A.P.A. Manual de Estadística Agraria. Madrid: Dirección General de Planif. Económica y Coord. Institucional. Ministerio de Agricultura, Pesca y Alimentación, 2000. 332p.
MARTINEZ, R.C. La uva de mesa embolsada del Vinalopó- única denominación de origen. Revista Fitopatologia y Entomologia, Madrid, v.19, n. 52, p. 60-63, 1997.

PIVA, C.R.. Modelo de evaluación de la Calidad y de las Preferencias del Consumidor para la uva de mesa. $2001.400 \mathrm{f}$. Thesis (Doctorate in Agrarian Economy) - E. T. S. I. Agrónomos, Universidad Politécnica de Madrid, Madrid, 2001.

POMMER, C.V.; PIRES, E. J. P.; TERRA, M. M.; PASOS, R. S. Streptomycin-induced seedlessness in the grape cultivar Rubi. American Journal of Enology and Viticulture, Davis, n.47, p.341342, 1996.

POOLE, N. D. Production and Marketing Strategies of Spanish Citrus Farmers. Journal of Agricultural Economics, Pennsylvania, n.51, p. 210-223, 2000. 